Trivent Publishing

(C) The Authors, 2016

Available online at http://trivent-publishing.eu/

Engineering and Industry Series

Volume Power Systems, Energy Markets and Renewable Energy Sources in

South-Eastern Europe

\title{
Problems, Barriers and Perspectives of RES Development in Poland
}

\author{
Waldemar Dolega ${ }^{1}$ \\ ${ }^{1}$ Department of Electrical Power Engineering, Faculty of Electrical Engineering, \\ Wroclaw University of Technology, Poland; Waldemar.dolega@pwr.edu.pl
}

\begin{abstract}
This paper describes selected current problems, barriers and perspectives of the development of renewable energy sources (RES) in Poland, while an analysis of the RES in Poland is done. The technical, economic and market potential of renewable energy sources in Poland is defined. Furthermore, the analysis and assessment of renewable energy sources in Poland in technical, economic and environmental aspects is made. The perspectives of the development of renewable energy sources up to 2020 in the context of the Polish implementation of EU's "3 3 20\%" climate package and the national quantitative target for RES development by 2020 are described. This paper also discusses selected technical, economic and legal problems, as well as certain barriers of the development of renewable energy sources in Poland. The conclusions contain the analysis of the barriers and perspectives of the development of renewable energy sources in Poland in the future.
\end{abstract}

\section{Keywords}

Renewable energy sources; development; legal regulations; RES investments; RES connection to the electric power network 


\section{Introduction}

Renewable energy sources (RES) record a dynamic development worldwide. Over the past twenty-five years, renewable energy has become an important electricity source in a number of countries, increasing their energetic independence and limiting the emission of pollutions. Their use is a major element of the sustainable development of each country and improves the local energy balance, saves energy fuels, reduces the emission of $\mathrm{CO}_{2}, \mathrm{SO}_{2}, \mathrm{NO}_{\mathrm{x}}$ and other pollutants into the air and lowers the costs of electricity acquisition [1].

In Poland, the development of RES is a chance to achieve an ecologic, lowemission electricity generation, higher energy security, and also a chance to meet the EU requirements with regard to energy generation from renewable sources. These requirements are connected to the implementation of the EU's " 3 x $20 \%$ " climate package by Poland and the national quantitative target for RES development by the year 2020 [2].

The Polish national 2020 target for renewable energy sources and energy efficiency is represented by the followings: a $15 \%$ share of energy generated from RES in the total primary energy; the reduction of $\mathrm{CO}_{2}$ emissions by $20 \%$; and the improvement of energy efficiency by $20 \%$ [3]. The development of RES will play a key role in achieving this target.

The RES in Poland comprise different types of distributed systems: biomass systems, biogas systems, photovoltaic systems, wind power plants and hydroelectric power plants. The systems differ greatly with regard to their equipment, the characteristics of their units, and their technologies. The costs of systems are strongly correlated with local conditions, market conditions and various support schemes [4].

The pace of development of the RES sector and especially the wind power industry in Poland has accelerated in recent years. But the growth rate of RES in Poland is still limited. This stems from a number of formal, legal and technical development barriers [5].

\section{Renewable energy sources in Poland}

At the end of 2015, the total RES capacity installed in Poland reached 6986 MW [6]. It was $17.3 \%$ share of the total installed capacity in the Polish Electric Power System (40455 MW) [6]. The total RES-installed capacity and the total amount of electricity produced in RES between 2010 and 2015 in Poland are shown in Table 1. 
Concerning wind power, a large increase in the installed capacity and in energy production has been observed in the past years. It stems from the high technological maturity of wind power, the increased output of individual wind turbines and wind farms and cost competitiveness compared to other renewable technologies used in Poland to produce electricity [7]. Wind energy is the main source of energy among renewable energy sources in Poland. It is a leader in the production of "green" electricity and also the fastest-developing renewable energy source in Poland. It is a similar phenomenon, much like in Europe, although on a much lesser scale. Wind power is the leading and prospective technology for combating global warming. Onshore wind power is the cheapest "green" electricity production technology in investment terms and exhibits the lowest cost range [8]. The same situation appears in terms of operational costs. Offshore wind power is not used in Poland. The first such installations will probably appear on the Polish territorial sea in 2020 [2].

Regarding biomass power, a relatively large increase in the installed capacity and in energy production has been observed in the past years. It mainly stems from biomass combustion and biomass joint combustion technology used in Poland to produce electricity [2]. Biomass energy is a second strong source for the production of "green" electricity in Poland.

Table 1. Cumulative power installation and electric energy production in RES in the years 2010-2015 in Poland [6]

\begin{tabular}{|l|l|l|l|l|l|l|l|}
\hline & Source & $\mathbf{2 0 1 0}$ & $\mathbf{2 0 1 1}$ & $\mathbf{2 0 1 2}$ & $\mathbf{2 0 1 3}$ & $\mathbf{2 0 1 4}$ & $\mathbf{2 0 1 5}$ \\
\hline $\begin{array}{l}\text { Nominal } \\
\text { power } \\
{[\text { MW] }}\end{array}$ & Biogas & 82.88 & 103.49 & 131.25 & 162.24 & 188.55 & 128.51 \\
\hline $\begin{array}{l}\text { Amount } \\
\text { of } \\
\text { produced } \\
\text { electricity } \\
{[\text { MWh] }} \\
\text { per year }\end{array}$ & Biogas & 363596 & 430537 & 529384 & 665143 & 782744 & 654710 \\
\hline $\begin{array}{l}\text { Nominal } \\
\text { power } \\
{[\text { MW] }}\end{array}$ & Biomass & 356.19 & 409.68 & 820.70 & 986.87 & 1008.24 & 1222.67 \\
\hline $\begin{array}{l}\text { Amount } \\
\text { of } \\
\text { produced } \\
\text { electricity } \\
{[\text { MWh] }} \\
\text { per year }\end{array}$ & Biomass & 635635 & 1101189 & 2208508 & 3281775 & 3013355 & 2829560 \\
\hline Nominal & Wind & 1180.27 & 1616.36 & 2496.75 & 3389.54 & 3833.83 & 4582.04 \\
\hline
\end{tabular}




\begin{tabular}{|l|l|l|l|l|l|l|l|}
\hline $\begin{array}{l}\text { power } \\
\text { [MW] }\end{array}$ & & & & & & & \\
\hline $\begin{array}{l}\text { Amount } \\
\text { of } \\
\text { produced } \\
\text { electricity } \\
\text { [MWh] } \\
\text { per year }\end{array}$ & Wind & 1823297 & 3128673 & 4612894 & 6077358 & 7624018 & 7271518 \\
\hline $\begin{array}{l}\text { Nominal } \\
\text { power } \\
\text { [MW] }\end{array}$ & Water & 937.04 & 951.39 & 966.10 & 970.13 & 977.01 & 981.80 \\
\hline $\begin{array}{l}\text { Amount } \\
\text { of } \\
\text { produced } \\
\text { electricity } \\
\text { [MWh] } \\
\text { per year }\end{array}$ & Water & 2922052 & 2316833 & 2031725 & 2439275 & 2180417 & 1482907 \\
\hline $\begin{array}{l}\text { Nominal } \\
\text { power } \\
{[\text { MW] }}\end{array}$ & $\begin{array}{l}\text { Photo- } \\
\text { voltaic }\end{array}$ & 0.03 & 1.12 & 1.29 & 1.90 & 21.00 & 71.03 \\
\hline $\begin{array}{l}\text { Amount } \\
\text { of } \\
\text { produced } \\
\text { electricity } \\
{[\text { MWh] }} \\
\text { per year }\end{array}$ & $\begin{array}{l}\text { Photo- } \\
\text { voltaic }\end{array}$ & 2 & 178 & 1178 & 1419 & 3848 & 29934 \\
\hline $\begin{array}{l}\text { Nominal } \\
\text { power } \\
{[\text { MW] }}\end{array}$ & Total & 2556,41 & 3082.04 & 4416.09 & 5510.68 & 6028.63 & 6986.05 \\
\hline $\begin{array}{l}\text { Amount } \\
\text { of } \\
\text { produced } \\
\text { electricity } \\
{[\text { [MWh] }} \\
\text { per year }\end{array}$ & Total & 5744582 & 6977410 & 9383689 & 12464970 & 13604382 & 12268629 \\
\hline
\end{tabular}

Regarding hydro power, only a small increase in the installed capacity has been observed in the past years, with an actual decrease in energy production. This situation stems from the depreciation of production assets, repairs, as well as lower flows and decreasing productivity per unit of installed capacity [5].

The growth rates in the RES sector and electricity production from RES have been significantly accelerating since 2010 . However, the considerable increase in the percentage data is still attributable to the low level of market development in absolute numbers. The RES sector in Poland is still in an early stage of development. Today, there are 2341 licensed RES installations operating 
nationwide (82 - biomass, 200 - biogas, 1039 - wind, 752 - water and 268 photovoltaic) [6].

Currently, the RES sector has significant further growth potential. The growing number of issued permits and projects under execution ensure the high pace of the RES development up to 2020 [6].

An important issue demonstrating the market potential of the RES sector is the presence in Poland of leading European and worldwide energy groups and producers of RES devices and equipment. Significant interest from foreign companies and their activity in Poland make the Polish RES sector dynamic. The conditions and development perspectives of the RES sector in Poland are good especially in area of wind power. Within the country attractiveness index of renewable energy, Poland was classified on the twentieth position. Poland was ranked ninth the European Union, whereas it was classified on the first position among new EU Member States and countries in Central and Eastern Europe [7].

The government plans that the total RES-installed capacity and yearly amount of produced electricity in RES by the end of 2020 will rise to $9380 \mathrm{MW}$ and $27331 \mathrm{GWh}$, respectively [2]. This will allow the reduction of $\mathrm{CO}_{2}$ emissions to $22680 \mathrm{kMg} /$ year [2]. Wind power will be the main RES technology used in Poland. By the end of 2020, the total wind installed capacity should increase to $6650 \mathrm{MW}$ and the total wind electricity production will increase to $15210 \mathrm{GWh}[8]$.

Intensive RES development in Poland requires solutions which raise numerous technical, economic and legal problems and thus a significant number of hindrances and formal, legal and technical development barriers [1]. Many of them are connected to the rapidly-changing legal environment. The most significant issues are legal procedures related to spatial planning and environmental impact assessments and problems with grid connection [1].

\section{Perspectives of the RES development in Poland}

The future development of RES in Poland will be connected to law regulations, the national energy policy, national renewable energy action plan, governmental undertakings, support systems and many other elements.

The RES sector in Poland is undergoing significant and continuous transformations. Until 2015, the Polish legislation did not have a dedicated piece of legislation of a statutory character which would comprehensively regulate conducting business activity in the field of renewable energy sources. The legal framework for the development of the renewable energy sector was exclusively set forth in the Energy Law [9]. The law regulated, among others, rules of 
granting support, connecting the RES to the grid, and conducting business activities within the production of electrical energy from renewable energy sources [9]. This state of affairs was changed in 2015, when the Polish Parliament adopted the Act on Renewable Energy Sources (RES Act) [10].

The main objective of the RES Act is to ensure the optimization and speeding-up of the development of renewable energy sources in Poland [10]. The law terminates the old support scheme based on certificates of origin (i.e. the so-called green certificates) and replaces it with the auction model. This is a fundamental change in financing the development of RES installations, from the well-known but lately unstable system of certificates to a cheaper solution which offers lower but more predictable support [7]. The auction system guarantees to the investors financial stability on the same level for the specified period. It is definitely more beneficial than the system of green certificates from the point of view of stability and predictability [7].

The RES Act, as mentioned, introduces a new support system for sources with a capacity exceeding $40 \mathrm{~kW}$; this is based on a contract for different models in which the guaranteed energy price will be settled through auctions [10]. The application of the auction mechanism results from Poland's action to implement the recommendation of the European Commission in the field of design for renewables support schemes. Although the RES Act came into force on May 4, 2015 , the provisions of the new rules for providing support will only be implemented from July 1, 2016 (starting January 1, 2016) [7].

The RES Act assumes a smooth transition from the system for certificates of origin to the auction system. Based on this, the RES installations which started energy generation before January 1, 2016, will receive support pursuant to existing conditions with the possibility to voluntarily change to the support in the auction system [10]. However, installations launched after December 31, 2015 will be eligible to receive support exclusively according to the new rules [10]. The producer will be able to combine the support received through auctions with the support from other sources, as part of state aid, up to the value of the reference price (the maximum value of the offer which can be submitted in an auction) [7].

According to the new rules, the support for RES energy producers will be granted through auctions of energy sales. Starting from 2016, auctions will be organized at least once a year by the President of the Energy Regulatory Office [10]. Furthermore, the Minister of Economy will define each year the amount of electrical energy which will be contracted for a period of 15 years through auctions. Auctions will be open to unfinished installations, whose design stage has been completed [10]. The producers participating in auctions will make sale 
offers for electrical energy which they will produce from their particular source for a period of 15 years. The offer should include the price of the energy for the said period of 15 years, as well as the quantity of energy they undertake in order to produce in the particular source during this period [7]. Offers with the lowest price will have priority for acceptance until the energy quota for auctions is used. The energy allocated for sale within a particular auction will be divided into separate "baskets" within which sale offers will be made.

A separate energy quota will be allocated for:

- Installations with a capacity not exceeding $1 \mathrm{MW}$, with the installed electrical capacity utilization factor below $4000 \mathrm{MWh} / \mathrm{MW} /$ year;

- Installations with a capacity not exceeding $1 \mathrm{MW}$, with the installed electrical capacity utilization factor of at least $4000 \mathrm{MWh} / \mathrm{MW} / \mathrm{year}$;

- Installations with a capacity exceeding $1 \mathrm{MW}$, with the installed electrical capacity utilization factor below $4000 \mathrm{MWh} / \mathrm{MW} / \mathrm{year}$;

- Installations with a capacity exceeding $1 \mathrm{MW}$, with the installed electrical capacity utilization factor of at least $4000 \mathrm{MWh} / \mathrm{MW} / \mathrm{year}$ [10].

The auction system guarantees the full competitiveness of all technologies which are to compete in one auction "basket." It may provide an impulse for the development of most economically-efficient technologies.

The support which the producers of electrical energy from renewable energy sources will be able to obtain in an auction will depend of the following factors:

- The amount and value of energy which may be contracted through an auction;

- The reference price, i.e. the maximum energy sale price which producers can offer during auctions;

- The number of auction participants, i.e. the installed connection capacity of the installations which will participate in an auction.

Each year, the Council of Ministers will define the amount of energy which will be purchased through auctions [10]. Within this amount, at least 25\% of electrical energy covered by the auction system should be generated in small installations with the capacity of up to 1 MW. For 2016, the maximum amount of produced electrical energy was defined on the level of $50449950 \mathrm{MWh}$ with the maximum value of PLN 18201331716 (where 1 PLN equals 0.22 EUR [11]) for all RES types [7].

The level of reference prices define the level of maximum support within state aid which the producer will be able to obtain apart from the support obtained in an auction [10]. The reference prices for 2016 are announced 
through a regulation of the Minister of Economy. The reference prices will be established separately for particular technologies and types of energy sources, as well as for the installed capacities of installations. The reference price for onshore wind power installations with the total installed electrical capacity below $1 \mathrm{MW}$ will be PLN 415/MWh, while for installations exceeding $1 \mathrm{MW}$ it will be PLN 385/MWh [7]. The reference price for RES installations which use offshore wind energy will be PLN 470/MWh [7]. The reference prices for photovoltaics with the capacity of up to $1 \mathrm{MW}$ will be PLN 465/MWh and for photovoltaics with a capacity exceeding $1 \mathrm{MW}$ - PLN 445/MWh [7].

The RES Act poses several problems. One of them is that it only offers the formal framework for the organization of tenders. Critical parameters of individual auctions remain in the hands of the Prime Minister or the Minister of Economy [7]. They will be the ones to determine whether in subsequent years the tenders will be allowed to build several thousands, hundreds or just a few dozens of MW of new capacities. They will also decide on the possibility of the migration of the producers from the certificate system to the contracts.

The new RES Act and the legislation concerning the first auction due to start in the second part of 2016, opens a new development phase for renewable energy sources in Poland. The RES sector will either grow or its development will become limited or halted, due to too restrictive auction parameters.

\section{Legal problems and barriers}

Legal problems also arise within the investment processes in the RES sector in Poland. The aspects of an investment project involved in the construction of plants include issues related to obtaining relevant decisions, licenses and administrative permits - all of these have significant influence on the development of RES [5]. It is relevant to process the implementation, the time and the profitability of the investment in the RES sector.

The administrative process starts with the decision concerning the construction of the RES installation and ends with the commission of the plant. This process is based on two main 33permits which need to be obtained: the first one is the construction permit and the second one concerns the connection of the RES installation to the power grid [5]. The problems are connected to the documents and analyses required to obtain the permits, as well as to the deadlines concerning the application examination by authorities.

The major stage of the implementation of an investment project is obtaining a real property on which to construct the renewable generation system. Polish law is complex in this respect. There are six forms based on which an investor is 
authorized to use the real property to construct and operate a RES, namely: ownership title, perpetual usufruct, lease of the real property, usufruct, real estate easement, and transmission easement [7].

The process of obtaining the legal title to the real estate for the location of the equipment and infrastructure of the RES installations starts at the very beginning of the investment and often lasts until its launch. The legal title must be obtained for all infrastructures, including the transmission infrastructure, the transformer stations, etc [7]. An ownership right is the best solution because it ensures the possibility to use the real estate in the widest possible scope without the need to obtain an additional legal title. The improper of the legal status to the real estate may significantly prolong the time frame for executing the investment [7].

The next important stage is the verification of the RES localization from the perspective of spatial development. It is based on a preliminary land development plan and a local land development plan or zoning decision [5].

RES installations are most frequently constructed based on the resolutions of the local zoning plans (LZP) adopted for the whole area of a commune or only for a part of it. The LZP is a law act of municipal units which defines the purpose and the conditions of land development and the locations of investments with a public purpose [7]. Adopting a new LZP or amending an existing LZP in order to construct RES installations is a prolonged process. When selecting a location for RES installations, it is necessary to verify in detail the local zoning situation in the particular area. Sometimes the conditions of a particular area clearly exclude the possibility of investments in infrastructure without adopting or changing the LZP [7].

The zoning decision (ZD) is an alternative instrument to the LZP for zoning plans. The aim of the $\mathrm{ZD}$ is to decide whether the particular investment project does not infringe the zoning order. Anyone can apply for zoning decisions regardless of the legal title to the real estate [7]. Obtaining the ZD is possible if there is no binding zoning plan for the particular area and if the lawful selected conditions are fulfilled. Due to the shorter period for obtaining documentation, the ZD has become the basic instrument for zone planning for locations of RES installations.

Obtaining permission for RES constructions requires a zoning decision that will define what type of facility and on what terms it can be implemented on a real property [5].

The following important stage of the implementation of a RES investment is to obtain a decision on environmental considerations. This defines the environmental conditions for executing the investment and constitutes one of the most difficult phases of project execution. 
The environmental impact assessment of the project (EIA) is a multistage long-lasting process whose aim is to protect the environment against the negative impact of the execution of the planned investment [12]. It consists of: the verification of the environmental impact of the investment report and obtaining the legally-required opinions and agreements. Local authorities have the duty to conduct the EIA process for the majority of the RES installations, especially wind farms which are projects with a potentially-significant impact on the environment [7]. The most optimum solution is to conduct the EIA process for the whole investment of the RES installation along with the transformer stations and the transmission infrastructure.

The report of the investment environmental impact should be drawn up for minimum three location alternatives: the description of the alternative proposed by the applicant, an second variant, and the alternative most beneficial to the environment [12]. Including in the report several investment variants with minimum and maximum parameters, will allow to introduce changes at the later stage of project execution without the need to run a supplementary EIA.

The defects and risks which may occur in the course of the EIA are connected with inappropriately ensuring the participation of the community in the proceedings, involving social organizations and incorrect monitoring [7].

Obtaining connection terms is one of most important stages of each investment preparation, because these terms warrant that within a specified time it will be possible to connect the RES installation to the grid; furthermore, they also indirectly define the maximum power of facilities to be installed within the RES system [5]. In order to connect to the grid, the investor should apply for connection terms to the transmission system operator (TSO) or distribution system operator (DSO) in the area where the plant will be constructed [9].

A key stage of the RES investment implementation is to obtain a construction permit. This is a decision which enables the commencement and the performance of the construction on the terms and conditions specified therein. The construction permit is issued when requested by an investor who has the right to dispose of the real property for construction purposes [5]. This permit should cover the whole construction intention. The application should be accompanied by (among other documents) a copy of the construction design and the permits required by law [5].

The typical investment development and execution stages for RES installations in Poland are as following [7]:

1. Selecting the RES installation location.

2. Analyzing the possibility of constructing a RES installation in the selected location. 
3. Obtaining approval for the construction of the RES installation from local authorities.

4. Conducting social consultations and obtaining approvals from the local community.

5. Drawing up or updating the zoning plan or obtaining a decision on land development.

6. Conducting analyses of different aspects of the RES installation, a multivariant selection of solutions, productiveness estimate, and determining the location of individual RES sets.

7. Analyzing the feasibility and costs of grid connection.

8. Drawing up the preliminary business plan.

9. Drafting the expert's opinion concerning the RES installation's impact on the National Electric Power System (NEPS).

10. Obtaining the rights to dispose of the land.

11. Obtaining the power grid connection terms.

12. Drafting the RES installation's environmental impact report.

13. Filing the application (with an appended report) for the decision concerning the environmental conditions with the municipality where the RES installation is to be established.

14. Obtaining the decision of the municipality concerning the environmental considerations of the investment (based on the decisions issued by the Regional Directorate for Environmental Protection).

15. Selecting the equipment supplier.

16. Developing the construction design for the construction permit purposes.

17. Drawing up the detailed business plan.

18. Obtaining the promise of the electric energy generation license.

19. Concluding the preliminary contract for sales of electrical energy and certificates of origin.

20. Concluding the connection agreement with the DSO/TSO.

21. Obtaining the construction permit(s).

22. Obtaining a promise of a bank loan or another guarantee for financing the project.

23. Obtaining a certificate allowing the participation in the auction (prequalification).

24. Winning the auction.

25. Executing the construction.

26. Agreeing on the co-operation instructions with the DSO/TSO.

27. Developing the terms and signing the respective sale agreements. 
28. Obtaining the energy generation license.

29. Obtaining the occupancy permit.

For the RES development in Poland, the long delay in the construction permit constitutes one of the major obstacles. This situation is connected to the ambiguity of the law and its terms of application by local governments, power companies or authorities. Multiple interpretations increase the risk of project failure. Additionally, organizations opposing the construction of new RES installations or the construction of RES installations in the proximity of residential areas exert high pressure on state administration with regard to both national legislation and the procedural methods applied in administrative proceedings by local governments [5].

The change of the support system will have a large influence on the RES development in Poland. Today, the greatest investment obstacle is the unpredictability of the consequences of the implementation of the auction system in Poland [7].

Generally, the main major legal problems in the RES area are connected to legal instability, unclear or uncertain legal regulations, as well as the complexity and lengthiness of administrative procedures.

The legal environment of the RES investments in Poland is undergoing rapid changes. Comprehensive regulations are not issued and frequent changes are implemented to already-existing legal regulations. For example, until the adoption of the RES Act, the Energy Law had been amended 66 times [7].

These legal problems lead to formal, administrative, and investment barriers. As the results of the formal barriers, the period of completion of an investment project in Poland is very long and it lasts, in average, from 4 to 7 years [5]. Each year, this period is getting longer. The actual project development phase, preceding the commencement of construction works, may last from 1 to 5 years, with the lower limit of the range referring to low-capacity projects [7]. The factor which mostly inhibits the investment preparation and the execution process is absence of clear regulations which are frequently interpreted based on the discretion and goodwill of administrative authorities. Among many examples of such obstacles are the prolonged processes of adopting/ amending provisions for the study of conditions and directions of land development [5]. Their lengthiness results from the fact that a large number of entities representing conflicting interests are involved in such procedures. Local authorities often have no interest to ensure a favourable climate for investors and they present passive attitude towards them [5]. Regulations or standard practices are not even in place, and, as a result, inconsistent decisions are issued. The poor quality of local legislation, combined with the duplication or even the evasion of legal 
regulations concerning environmental protection by local governments substantially hinders investment planning and implementation [7].

The key barriers for the RES development in Poland, according to investors, are the following:

- The lack of clear policies for the RES development,

- The uncertain and unstable law,

- The unpredictability of the consequences of the auction system implementation,

- The procedures related to environmental protection,

- The overgrowth of formal obligations and lack of competence of relevant authorities,

- The social protests of local communities,

- The lack of a permanent or long-term financial support system for the investor,

- The grid connection policy of the DSO/TSO,

- The difficulties in obtaining grid connection,

- The lack of sufficient grid infrastructure.

\section{Technical problems and barriers}

The connection of the RES installations to the grid creates the main technical problems and barriers in Poland. RES installations are connected to the electric power network by the proper system operator (on whose operating territory the connection is to take place) on the basis of a network connection agreement, provided there exist technical and economic conditions for connecting to the network and receiving electric energy [5]. RES installations can be connected to the network only after the investor fulfils the network connection terms and conditions specified by the proper system operator, including the technical conditions defined in the ordinance on detailed conditions for the operation of the power system [5]. The terms and conditions will be specified provided the entity applying for connection to the network prepares and submits a proper application.

The technical problems encountered within RES development are connected to the technical conditions of the National Electric Power System (NEPS) which make infrastructural limitations. The main factors for such situations are the absence of essential and necessary investments in system modernization and the development and absence of an effective mechanism ensuring investments by system operators [7]. 
The existing network infrastructure for transmission and distribution indicates significant shortages both with regard to meeting the current demand and that in the nearest future, as well as with regard to the degree of wear and tear and failure proneness of the existing lines [12]. The security of energy supply in Poland is jeopardized by the deteriorating technical conditions of power infrastructure. For example, the majority of transformers and transmission lines with voltage of $400 \mathrm{kV}$ or $220 \mathrm{kV}$ were built in the 1970s and 1980s [7]. As much as $82 \%$ of the facilities using $220 \mathrm{kV}$ voltage are older than 30 years and the majority of them were built in the 1950s and 1960s, $17 \%$ are between 20 and 30 years old and only $1 \%$ are more recent than 20 years [6]. In the case of transmission lines with $400 \mathrm{kV}$ voltage, $25 \%$ of the facilities are over 30 years old, 56\% are between 20 and 30 years old, and 19\% are younger than 20 years [6].

Polish power grids are outdated and underdeveloped. The system structure is designed to collect power from a few large sources located mainly in the south part of Poland, and not from the numerous other sources with lower capacity. It is necessary to develop a transmission and distribution system and receive electricity from the areas with high density of planned and newly-established RES installations [12].

The technical condition of the grid infrastructure has been constantly deteriorating. The key reasons of this situation are the bureaucratic administrative procedures, the lack of legal solutions facilitating investments and modernizations and also the lack of an efficient mechanism enforcing the execution of the investments [12].

The absence of appropriate investments in the transmission \& distribution infrastructure limits the RES development. The lack of appropriate legal solutions makes transform investment projects in the RES sector into timeconsuming and expensive projects, which also present the risk that the investment process may be abandoned (either due to connection conditions or environmental decision/building permit issues); thus the risk of failure is higher in RES investment projects than in other areas of business activity [5].

The support scheme in the period up to 2020 in Poland primarily aims to solve crucial grid connection issues and to support the construction of RES installations [5].

The support applies to the necessary actions for grid infrastructure development and the grid access principles for investors who build and connect RES installations to the grid. The grid development dynamics and its adaptation should have a direct connection to the RES development programme [8]. 
Grid infrastructure development is costly and time-consuming, therefore long-term plans and wide investment actions are necessary [12].

Investment plans constitute a key component for development plans adopted by system operators (TSO, DSO). In Poland, the terms of reference and schedules of such investments are taken into consideration by the President of the Energy Regulatory Office during the tariff approval process [12]. However, the system modernization and development process is long and expensive. Consequently, long-term income and cost forecasts developed by operators are by default predisposed to a high margin of error. During the price setting process, the President of ERO assesses the material interests of both the power company and the consumers [9]. The outdated infrastructure forces investments, but the scale of such investments - limited by the financial and crediting abilities of the operators - is insufficient in comparison to the desired development of the national energy generation system. From this perspective, the entire transmission and distribution system is undercapitalized, and substantial growth of investment scale cannot be expected until this problem is solved [5].

Different problems related to connecting renewable energy sources to the grid can be seen below:

- Grid connection refusal,

- Inaccessibility of the system information,

- Connection terms without power collection guarantee,

- RES connection costs,

- Virtual agreements,

- Connection limitations arising from the operators' development plans.

The refusals to connect the RES installation to the grid are some of the most important factors slowing down the development of the RES sector. Procedural hurdles invented by system operators (TSO, DSO) often cause delays or refusals to issue connection terms [5]. Two of the common practices are the following: requesting multiple supplements to the applications submitted, or adding multiple comments to the expert's opinion on the impact of the RES installation connection on the NEPS submitted by the investor and requesting respective changes to this opinion [7]. Moreover, it often happens that system operators adopt extremely unfavourable impact scenarios of a new source connection on the transmission system or distribution system [5].

System operators have the obligation to draw up and publish information on entities seeking connection to the power system with a rated voltage which exceeds $1 \mathrm{kV}$, and the volume of available connection capacity with a rated voltage exceeding $110 \mathrm{kV}$, taking into consideration any changes planned for the 
subsequent 5 years [9]. Generally, system operators formally meet this obligation. They often present statements that are vague, e.g. that indicate the total capacity of the RES which can be connected to their infrastructure without offering the specifics of the location. Such information is insufficient for investors, and the lack of detailed data concerning access to the system constitutes a gross impediment to the investment preparation process [5].

Sometimes, the system operators, upon issuing the connection terms, make an observation that they cannot guarantee the full collection of power from the power plant until relevant infrastructural investments are completed [5]. Additionally, they indicate that they are unable to offer any binding deadline for completion of such investments, while simultaneously requiring investors to complete their projects on time.

The RES connection costs belong to the most important factors which slow down the development of the RES sector. Often, system operators charge steep connection fees that compensate for modernization and development costs of the system owned by the operator [5]. The fees are highly diversified. They range between over a dozen thousand PLN to even PLN 4 million per 1 MW of the connection capacity [7]. It is directly connected to the imprecise law which does not state directly if and to what extent the investor has the obligation to bear the costs of developing the infrastructure which is the property of the grid operator.

The latest legal regulations introduced restrictions with regard to the acquisition of connection terms, limiting at the same time investor's ability to reserve connection potential [9]. This change aimed to unlock the procedures followed by system operators when issuing connection terms, as well as the total volume of applications submitted without restrictions (and often just speculatively), which actually led to the suspension of the proceedings [5]. As a consequence, the so-called "virtual agreements" blocked access to the grid.

System operators have the obligation to draw up development plans regarding the satisfaction of present and future energy demand for the perspective of minimum 5 years [9]. Moreover, operators are required to develop forecasts with regard to the security of electricity supply for a period of no less than fifteen years. By principle, development plan drafts are consulted with the President of the Energy Regulatory Office [9]. The plans are inspected with regard to, among others, their conformance to the local land development plan (or commune development directions defined in land development conditions and directions studies), and the degree of completion of energy supply plans adopted by commune councils [5]. In practice, operators often use their own plans as a basis to refuse or delay the connection of RES installations, e.g. if investments are planned in different locations or scopes of works [5]. 


\section{Conclusions}

The RES development in Poland is a chance to achieve ecological, low-emission electricity generation, higher energy security, while also meeting the EU requirements regarding energy generation from renewable sources.

The RES development in Poland requires solutions of many technical, economic and legal problems which raise a number of hindrances, as well as formal, legal and technical development barriers.

The key barriers the RES development in Poland faces are connected with: the lack of clear policy from the state for RES development, the uncertain and unstable law, the complexity and lengthiness of procedures, the unpredictability of consequences of the auction system implementation, the complex procedures related to environmental protection, the overgrowth of formal obligations and lack of competence of the relevant authorities, the social protests of local communities, the lack of a permanent or long-term financial support system for investors, the grid connection policy of DSO/TSO, the difficulties with obtaining grid connection, and the lack of sufficient grid infrastructure.

The technical problems regarding the connection of RES installations to the grid are mainly connected to: the absence of essential and necessary investments in system modernization and development, as well as the absence of effective mechanisms to ensure investments by system operators. Some special problems concern: grid connection refusal, inaccessibility to system information, connection terms without power collection guarantee, RES connection costs, virtual agreements, and connection limitations arising from operators' development plans.

The new RES Act and implementing legislation concerning the first auction open a new phase of development for renewable energy sources in Poland. This can be a phase of increase, limitation or stoppage of the RES sector.

\section{References}

[1] Dolega, W. "Selected problems of microgeneration development in Poland," 10-th Jubilee International Conference on Deregulated Electricity Market Issues in South-Eastern Europe DEMSEE 2015, Budapest, Hungary, 24-25 September 2015, paper 15.

[2] National renewable energy action plan for Poland. Ministry of Economy, Warsaw 2010. (In Polish) 
[3] Announcement of Ministry of Economy from 21.12.2009 in a matter of the national energy policy up to 2030 (Monitor of Poland of 2010 No.2, Item 11). (In Polish)

[4] Dolega, W. "Analysis and assessment of support mechanisms for the promotion of renewable energy sources - case study Poland," 6-th International Workshop on Deregulated Electricity Market Issues in SouthEastern Europe DEMSEE 2011, Bled, Slovenia, Sep. 20-21, 2011. Zalozba FE in FRI, paper 087.

[5] Dolega, W. "Selected problems of RES development in Poland," 8-th International Conference on Deregulated Electricity Market Issues in South-Eastern Europe DEMSEE 2013, Cavtat, Croatia, Sep. 24-25, 2013, paper 36.

[6] Activity of the President of Energy Regulatory Office in 2015. Report, The Energy Regulatory Office, Warsaw, 2016. http://www.ure.gov.pl/ pl/urzad/informacje-ogolne/ sprawozdania/ 2916, Sprawozdania.html (In Polish) (accessed July 1, 2016)

[7] Wind energy in Poland 2015/2016. IDZP, TPA Horwath. Report, November 2015. http://www.tpa-horwath.pl/pl/p/publikacje/ publikacje (accessed July 1, 2016)

[8] Wisniewski G. and others, "Wind power development in Poland by 2020 a vision". A report developed for Polish Wind Energy Association, Institute for Renewable Energy, Warsaw, November 2009.

[9] Act of 10 April 1997 - The Energy Law (Journal of Laws of 2006 No.89, Item 625, with later changes). (In Polish)

[10] Act of 20 February 2015 - on Renewable Energy Sources (Journal of Laws of 2015 Item 475, with later changes). (In Polish)

[11] Average foreign exchange rates - Polish National Bank [Online]. http://www.bankier.pl (In Polish) (accessed July 1, 2016)

[12] Dolega, W., The planning of electric power network infrastructure development with regard to energy supply security and environmental safety, Published House of the Wroclaw University of Technology, Wroclaw, pp. 127-151. 2013. 